\title{
INTEGRALISTIK-INTERKONEKTIF PENDIDIKAN SALAF DAN KHALAF PONDOK PESANTREN TEBUIRENG JOMBANG
}

\author{
Moch. Khoirul Walid \\ Universitas Islam Negeri Sunan Kalijaga Yogyakarta, Indonesia \\ walidchoirul@gmail.com
}

\begin{abstract}
Along with the development of the education system in Indonesia, pesantren are classified into two parts, namely the Salafi pesantren (pesantren that maintains classical traditions) and the Khalafi pesantren (pesantren that incorporate general knowledge or open school institutions). Not all educational institutions have integrated relationships with other knowledge, but from several Islamic boarding schools, there are many that have integrated salaf and khalaf education, such as the one in Pondok Pesantren Tebuireng Jombang.
\end{abstract}

\section{ABSTRAK}

Seiring perkembangan sistem pendidikan di Indonesia, pesantren diklasifikasikan menjadi dua bagian yaitu pesantren Salafi (pesantren yang mempertahankan tradisi klasik) dan pesantren Khalafi (pesantren yang memasukkan pengetahuan umum atau membuka istitusi lembaga sekolah atau madrasah). Tidak semua lembaga pendidikan memiliki integrasi keterhubungan dengan pengetahuan lain, namun dari beberapa pondok pesantren sudah banyak yang mengintegrasikan pendidikan salaf dan khalaf seperti yang ada di Pondok Pesantren Tebuireng Jombang.

\section{ARTICLE HISTORY}

Received 01 Mei 2021

Revised 02 Juni 2021

Accepted 01 September 2021

\section{KEYWORDS}

Pendidikan, Integrasi,

Pondok Pesantren 
Moch. Khoirul Walid, Integralistik-Interkonektif Pendidikan Salaf dan Khalaf Pondok Pesantren Tebuireng Jombang

DOI: https://doi.org/10.19105/rjpai.v2i2.4645

\section{PENDAHULUAN}

Indonesia merupakan Negara besar yang memiliki beberapa fasilitas dalam berbagai bidang yang memiliki fungsional penting terhadap kebutuhan masyarakat, salah satunya yaitu lembaga pendidikan yang berfungsi sebagai sarana penunjang wawasan dan pengetahuan seseorang dalam memprbaiki diri. Pada dasarnya, pendidikan merupakan aspek penting yang harus dikonstruksi manusia untuk menjadikan pribadinya menjadi lebih baik, terarah, dan tidak primitive. Pusat pendidikan di Indonesia terdiri atas pendidikan berbasis umum dan Islami yang diterapkan diberbagai lembaga formal maupun informal (baca: pesantren).

Pesantren merupakan lembaga pendidikan Islam tertua di Indonesia sejak ratusan tahun silam, khususnya di Jawa. Pesantren dapat dikatakan sebagai budaya Indonesia yang memiliki relasi tidak hanya sebagai lembaga pendidikan, tetapi juga sebagai lembaga sosial dan media penyiaran terkait keagamaan. Pesantren sangat melekat dan memiliki integritas dengan masyarakat karena sumbangsi pengetahuannya sebagai tuntunan moral dan menjawab tantangan zaman bagi masyarakat baik di pedesaan maupun perkotaan. Karena metode pengajaran yang diprioritaskan pesantren kepada para santri selain memberikan penerapan membaca al-Qur'an juga mengkaji kitab klasik dengan beberapa metode pembelajaran serta model kajiannya secara bertahap sesuai tingkat pengetahuan santri.

Dewasa ini, memang yang nampak dalam bingkai kehidupan manusia yaitu Era Globalisasi. Sejarah mencatat bahwa globalisasi memang sudah lama hadir, namun baru beberapa kurun waktu ini dapat dirasakan reaksi atau dampak yang signifikan. Dari dampak negatif maupun positif yang dapat dirasakan yaitu dalam bidang pendidikan Islam. Salah satu dari hal tersebut yakni dalam dunia pesantren di Indonesia khususnya di Jawa. Modernisasi tersebut, membuat ilmu pengetahuan harus disikapi dengan baik dimana sebagian dari masyarakat telah masuk dalam tahap berpikir secara rasional sehingga memunculkan bangunan metodologi yang menjamin akan kebenaran 
terkait temuan dari pengetahuan manusia. Seperti halnya masyarakat yang mengokohkan keyakinan dan kebenaran agama, maka dinilai sebagai masyarakan non-rasional yang subjektif dan diidentikkan dengan bangsa timur sedangankan non-barat diidentikkan dengan masyarakat primitif atau lebih jelasnya yaitu masyarakat timur cenderung primitif sedangkan barat cenderung berkembang (baca maju). ${ }^{1}$ Sekitar awal abad ke-19, lembaga pendidikan Islam sudah mulai mereduksi pendidikan modern (sekuler) yang menjadi tuntutan pesantren dalam peningkatan kualitas pendidikan. Sehingga, hal tersebut menjadi suatu opsi dilematis antara mempertahankan kultur pendidikan Islam dan menyikapi system pendidikan modern. ${ }^{2}$ Oleh karena itu, melihat realita tersebut mau tidak mau harus menjadi tuntutan untuk melakukan pembenahan karena eksistensi pesantren sangat memberikan kontribusi yang banyak dan bermanfaat bagi masyarakat, termasuk dalam menyikapi berbagai tantang modernitas yang terjadi sejak kolonialisme sampai materialism, kapitalism, dan industrialism.

Seiring perkembangan sistem pendidikan di Indonesia tersebut, pesantren diklasifikasikan menjadi dau bagian yaitu pesantren Salafi (pesantren yang mempertahankan tradisi klasik) dan pesantren Khalafi (pesantren yang memasukkan pengetahuan umum atau membuka istitusi lembaga sekolah atau madrasah). ${ }^{3}$ Pada realitanya, tidak semua lembaga pendidikan memiliki integrasi keterhubungan dengan pengetahuan lain. Namun dari beberapa pondok pesantren dirasa memang sudah banyak yang mengintegrasikan pendidikan salaf dan khalaf, namun fokus kajian ini mengarah pada pesantren yang ada di Jawa Timur yaitu pesantren Tebuireng Jombang yang memiliki keterhubungan beberapa basis pendidikan dalam menyikapi tantangan zaman.

\footnotetext{
${ }^{1}$ Noeng Muhadjir, Filsafat Ilmu; Kualitatif dan Kuantitatif dan kuantitatif untuk Pengembangan Ilmu dan Penelitian, Ed. 3 (Yogyakarta: Rake Saeasin, 2006), hlm. 101.

2 Mu'awanah, Manajemen Pesantren Mahasiswa; Studi Ma'had UIN Malang (Kediri: STAIN Kediri Press, 2009), hlm. 3-4.

${ }^{3}$ Zamakhsyari Dhofier, Tradisi Pesantren: Studi tentang Pandangan Hidup Kyai (Jakarta: LP3ES, 1984), hlm. 41.
} 
Pondok pesantren Tebuireng jombang merupakan pondok yang masyhur di Indonesia baik kalangan ilmuan, elit, dan politik dengan karakteristik pesantrennya. Pesantren tersebut berkembang pesat sejak abad ke20 dengan mengadopsi sistem pendidikan kolonial belanda hingga sekarang diwariskan kepada penerusnya yang juga memiliki kompetensi mengatur dan mengembangkan pesantren. Sehingga pesantren tersebut semakin berkembang hingga sekarang dengan karakter yang tidak hanya salafi, melainkan juga khalafi.

\section{METODE PENELITIAN}

Dalam membantu kajian tersebut karena penelitian ini mengarah pada studi kasus pada lembaga pendidikan pesantren Tebuireng Jombang Jawa Timur. Maka, penulis menggunakan penelitian bentuk Kualitatif 4 dengan merujuk pada sumber metode penelitian terdahulu yang bersifat Field Reaserch. ${ }^{5}$

Peneliti ini juga menggunakan beberapa metode dalam mengumpulkan data diantaranya sebagai berikut:

\section{Wawancara}

Metode pengumpulan data melalui informasi dengan cara melakukan komunikasi bentuk dialog tanya jawab secara langsung maupun tidak langsung dengan pelaku yang memiliki sumber data. ${ }^{6}$ Keterbatasan situasi dan kondisi, membuat penulis menggunakan alternatif daring dalam menjangkau data dengan media.

2. Dokumentasi

\footnotetext{
${ }^{4}$ Suatu metode pemahaman yang membantu untuk menanggapi fenomena-fenomena yang terjadi sesuai yang dialami oleh subjek penelitian secara holistic dengan analisis deskriptif melalui kata-kata dan bahasa dalam konteks tertentu. Lihat: Lexy j. moleong, Metode Penelitian Kualitatif (Bandung: PT. Remaja Rosdakarya, 2010), hlm. 6.

${ }^{5}$ Metode yang berhubungan lapangan. Lihat: Saifuddin Anwar, Metode Penelitian (Yogyakarta: Pustaka Pelajar, 1999), hlm. 17.

${ }^{6}$ Jumhur, dan M. Suryo, Bimbingan dan Penyuluhan di Sekolah (Bandung: CV. Ilmu, 1975), hlm. 50.
} 
Teknik dokumentasi ini dalam wujud pengumpulan data berupa arsiparsip tertulis. ${ }^{7}$

\section{HASIL DAN PEMBAHASAN}

Pesantren Tebuireng merupakan pesantren yang didirikan oleh Khadratus Syekh K.H. Hasyim Asy'ari ${ }^{8}$ pada tanggal 26 Robi'ul awal 1317 H/ 3 Agustus 1889 M. Nama Tebuireng pada mulanya adalah nama desa yang mayoritas penduduknya memiliki kebiasaan buruk yakni berjudi, mabuk, mencurui, membegal, berzina dan sabung ayam. Keprihatinan tersebut dan dorongan dari beberapa kyai untuk membrantas kebiasaan tersebut dengan mendirikan pondok pesantren di desa tersebut sebagai bentuk jihad. Pada akhirnya beliau membeli sepetak tanah dari seorang dalang desa tersebut dan membangun sebuah bangunan sederhana dari (jawa: tratak) anyaman bambu dengan luas sekitar 10 meter persegi yang terdiri atas tempat tinggal kyai dan tempat mengaji dan ibadah para santri. Seiring perkembangan berdirinya pesantren tersebut, kapasitas santri yang semula hanya 8 orang, bertambah menjadi 28 orang di tahun 1910 hingga 10 tahun berikutnya bertambah sekitar 2000 santri sehingga pesantren mengalami perluasan bangunan dan peningkatan kegiatan pendidikan untuk menguasai kajian teks-teks kuno atau kitab-kitab klasik dari pemikiran empat madhab. ${ }^{9}$ Pendidikan pesantren tersebut semakin berkembang seiring dengan bertambahnya santri.

Pada tahun 1919, K.H. Hasyim Asy'ari merubah system pendidikan yang menerapkan system madrasi (klasik) dengan mendirikan Madrasah Salafiyyah Syafi'iyyah yang berjenjang dalam dua tingkatan Słifr Awal dan Słifr Thaniy. Kemudian dilakukan pembaruan lagi pada tahun 1929, dengan

\footnotetext{
7 Dalam realisasinya, model pengumpulan data ini dengan mengambil foto-foto terkait kebutuhan penelitian. Lihat: Margono, Metodologi Penelitian Pendidikan (Jakarta: Rinekha Cipat, 2003), hm. 181.

8 Putra kyai Asy'ari yang lahir pada 28 Dzul Qa'dah 1287 H/ 14 Februari 1871 di pondok pesantren Gedang Jombang, secara detailnya, Lihat: Akarhanaf, Kyai Hasjim Hasj'ari; Bapak Umat Islam Indonesia (Jombang: t.np, 1949), hlm. 157

${ }^{9}$ Dokumentasi Sekretaris Pesantren Tebuireng Jombang.
} 
Moch. Khoirul Walid, Integralistik-Interkonektif Pendidikan Salaf dan Khalaf Pondok Pesantren Tebuireng Jombang

dimasukkannya pelajaran umum dalam sistem pengajaran. Hal tersebut menimbulkan beberapa reaksi dari kalangan masyarakat, ulama', dan wali santri, dikarenakan pada saat itu belum ada pesantren yang menggunakan sistem demikian, sehingga banyak wali santri yang ragu dan memulangkan anaknya. Penerapan pendidikan seperti itu tidak dimiliki beberpa pesantren pada saat itu karena presepsi masyarakat islam di Indonesia mengklaim bahwa hanya pendidikan agama yang dapat menjawab segala macam persoalan serta mengklaim bahwa pendidikan umum yakni sebagai kemungkaran dan budaya belanda. Namun, sistem madrasah tersebut tetap dioptimalkan pesantren tebuireng karena dirasa ilmu umum sangat diperlukan santri di masa depan. Perkembangan tersebut berjalan selama 7 perieode yaitu kyai Hasyim Asy'ari (1899-1947), K.H. Abdul Wachid Hasyim (1947-1950), K.H. Abdul Karim (19501951), K.H. Ahmad Baidhawi (1951-1952), K.H. Abdul Kholiq (1953-1965), K.H. Muhammad Yusuf Hasyim (1965-2006) K.H. Shalahuddin Wahid (2006-2020). ${ }^{10}$

Pada dasarnya pesantren salaf identik dengan metode pembelajaran yang dikenal kalangan santri yakni sorogan dan bandongan sepertihalnya yang diterapkan kyai Hasyim sejak berdirinya pesantren Tebuireng. Pada tahun 70an, K.H. Abdurrahman Wahid membumikan pesantren menjadi sub-kultur dari bangsa indonesia dan diketahui oleh umat islam sebagai model institusi pendidikan yang memiliki keunggulan. ${ }^{11}$ Dengan mengintegrasikan antara sisi transmisi dan moralitas muslim tersebut, perlunya dukungan dari intelektual muslim sebagai pengembalian pesantren kepada jati diri yang sebenarnya dalam menghadapi zaman modern. Karena pada dasarnya pesantren merupakan lembaga pendidikan islam yang tumbuh serta berkembang dari masyarakat dan kembali ke masyarakat. ${ }^{12}$

10 Tim Penyusun, Buku Panduan Santri Tebuireng (Jombang: Pengurus Pondok Pesantren Tebuireng, 2014), hlm. 26.

${ }^{11}$ Malik Fajar, Visi Pembaharuan Pendidikan Islam (Jakarta: LP3N, 1998), hlm. 126

12 Anin Nurhayati, Inovasi Kurikulum; Telaah Terhadap Pengembangan Kurikulum Pendidikan Pesantren (Yogyakarta: Teras, 2010), hlm 51. 
Bertolak pada zaman dulu, di era globalisasi perkembangan ilmu dan pengetahuan (IPTEK) ini banyak masyarakat yang meragukan eksistensi lembaga pesantren yang dilatarbelakangi kecenderungan basis pendidikan pesantren-pesantren dalam bersikap tertutup dan kolot dalam menyikapi setiap perkembangan zaman. Menurut Ayumardi Azra, kekolodan pesantren dalam mereduksi hal-hal yang berbau modern. ${ }^{13}$ Selain itu, pesantren juga dihadapkan terhadap tuntutan untuk berkontribusi meningkatkan mutu pendidikan dan SDM dalam era globalisasi. ${ }^{14}$ Perkembangan tersebut membuat pesantren yang diketahui masyarkat sebaga lembaga informal tertinggal dengan lembaga formal dengan terwujudnya beberapa sekolah bertaraf nasional yang berstatus negeri dan dengan kurikulum resmi dari departemen agama maupun departemen pendidikan nasional. Serta dilatarbelakangi oleh dikhotomi bahwa pendidikan formal mengahsilkan ijazah yang menjamin keberhasilan dalam bidang pekerjaan dan politik.

Tipologi pesantren Tebuireng yakni sebagai pesantren yang selain memprioritaskan pendidikan salafi juga mengintegrasikan pendidikan khalafi. Tergolong pesantren salafiyyah plus dimana pesantren ini tidak hanya memberikan pengajaran yang berkutat pada kitab klasik (santri: kitab kuning) saja, melainkan pengajaran formal jalur sekolah dan perguruan tinggi. ${ }^{15}$ Berdasarkan Dokumentasinya, pesantren tebuireng mendirikan madrasah periode kyai Hasyim hingga beberapa periode sesudahnya sebagai penyempurna seperti pada periode ke-2 dengan mendirikan madrasah nidhomiyah, pada periode ke-3 mendirikan sekolah persiapan (SP), periode ke4 memberlakukan sispem pendidikan dan mengenalkan pelajaran umum, periode ke-5 dengan melakukan pembenahan sistem pendidikan dan menekankan kajian kitab kuning, periode ke-6 dengan mendirikan Universitas

\footnotetext{
${ }^{13}$ Ayumardi Azra, Pendidikan Islam, Tradisi dan Modernitas Menuju Milenium Baru (Jakarta: Logos Majalah Ilmu, 2000), hlm. 21

${ }^{14} \mathrm{Mu}$ 'awanah, Manajemen Pesantren Mahasiswa..., hlm. 4.

${ }^{15}$ Imron Arifin dan Muhammad Selamet, Kepemimpinan Kyai dalam Perubahan Manajemen Pondok Pesantren Tebuireng; Studi Kasus Pesantren Tebuireng Jombang (Yogyakarta: CV. Aditya Media, 2010), hlm. 34.
} 
Moch. Khoirul Walid, Integralistik-Interkonektif Pendidikan Salaf dan Khalaf Pondok Pesantren Tebuireng Jombang

dan madrasah Hufadh, dan periode ke-7 dengan melakukan pembenahan struktur baik fisik maupun non-fisik dan mendirikan madrasah mu'allimin, ma'had ali, dan madrasah diniyah. ${ }^{16}$ Seperti yang diketahui saat ini, bahwa pendidikan yang dimiliki pesantren terdapat dua model yakni pendidikan salaf terdapat pada madrasah mu'allimin, madrasah diniyah, dan ma'had aly, sedangkan pendidikan khalaf terdapat di Mts, SMP, SMA, Madrasah Aliyah, dan UNHASY.

Metode pembelajaran yang diterapkan pesantren tebuireng merupakan integritas interkonektif antara pendidikan agama dengan pendidikan umum berkat kompetensi pengasuh beserta struktur penjamin mutu dan majlis ilmi pesantren berdasarkan ketentuan undang-undang SKKB yang berlaku. Namun bukan berarti pesantren tebuireng meninggalkan jati diri pada pendidikan salaf, akan tetapi tetap menekankan kajian salafnya bahkan memberikan kurikulum pelajaran salafi dalam setiap sekolah dan perguruan tinggi seperti ilmu tafsir, ilmu hadis, ilmu faraid, dan ilmu balagha.

\section{PEMBAHASAN}

Awal tahun 1997-1980 kajian di Indonesia masih terlalu kental dengan dunia paradigma dokmatisme pengetahuan, bagaimana klaim-klaim kebenaran agama menjadi terkotak-kotakkan sesuai dengan kelompoknya. Wajar jika Amin Abdullah merasa gelisah terhadap fenomena yang seperti itu, karena sejarah pemikirannya belajar dari berbagai entitas dan kemudia ia mencoba untuk peraktekkan bahwa banyak realitas dan entitas lain yang berbeda dengan tidak hanya selalu mengkotak-kotakkan kebenarannya sesuai dengan kelompoknya. Tentunya dalam merasakan kegelisahan tidak hanya semerta-merta melihat banyaknya realitas yang hanya berdiri sendiri dengan klaim-klaim kebenarannya saja, akan tetapi dari sekian kegelisahan yang ia hadapi minimal ada 4 kegelisihan yang disebut oleh Alim Ruswantoro dalam “Islam, Agama-

${ }^{16}$ Dokumentasi Sekretaris Pesantren Tebuireng Jombang. 
agama dan Nilai Kemanusiaan". Yakni masalah klaim kebenaran, tantangan globalisasi, dikotomi keilmuan, dan pendekatan yang kering dari historisitas.

Pertama, klaim kebenaran, tampaknya dalam hal ini bahasa yang digunakan Amin Abdullah dengan penyebutan klaim kebenaran dan pergeseran paradigma ini mereduksi dari Pemikir Islam M. Arkoun dan Thomas Samuel Khun, bahwa klaim kebenaran atas nama pemikiran islam tidak bisa dibenarkan, karena dalam klaim kebenaran jelas sekali sudah menutup kemungkinankemungkian yang berbeda dengan kelompoknya sehingga apa apa yang berbeda dengan kelompok tertentu akan disalahkan karena perbedaannya, padahal yang namanya pemikiran akan selalu berubah karena selalu terikat dengan situasi dan kondisi yang selalu berganti. ${ }^{17}$ Di sisi lain, pemahaman atau pemikiran atas agama juga seharunya selalu memiliki corak yang tidak hanya lurus dengan satu cara saja, karena segala fenomena yang berhubungan pada saat itu selalau berbenturan dengan fakta dan ide baru termasuk dalam pemikiran agama, sehinggga di sini dianggap perlunya pendekatan lain untuk menyempurnakan agama itu sendiri, sehingga jika hanya terus mempertahan klaim kebenaran hanya menurut kelompok tertentu maka hal tersebut yang bahkan menenggelamkan islam bahkan akan menimbulkan kekerasan atas nama agama karena di setiap kelompok memiliki standar kebenaran yang tidak bisa ditawar. ${ }^{18}$

Kedua, Dikotomi Keilmuan Islam, bagaimana kajian agama seringkali dianggap tidak ilmia oleh sains, dan begitupula agama sesekali memandang ilmu sains dengan sebelah mata karena tidak langsung bersumber dari tuhan sehingga kemudian dari anggapan ini terdapat perbedaan antara agama dan ilmu sains atau disebut dengan dikotomi pengetahuan. ${ }^{19}$ Dalam perkembangan pengetahuan agar terhindar dari apa yang disebut dengan dikotomi pegetahuan, Amin Abdullah menawarakan gagasan yang bersifat kritis, yakni

17. Alim Ruswatoro, Epistemologi Pemikiran Islam M. Amin Abdullah Islam, dalam Agama Islam dan Nilai Kemanusiaan (Yogyakarta: Center For The Study Of Islam and Social Transformation UIN Sunan Kalijaga, 2013), hlm 8.

18. Alim Ruswatoro, Epistemologi Pemikiran Islam, hlm. 8.

19. Alim Ruswatoro, Epistemologi Pemikiran Islam, hlm. 9. 
Moch. Khoirul Walid, Integralistik-Interkonektif Pendidikan Salaf dan Khalaf Pondok Pesantren Tebuireng Jombang

agama (teks agama) diperlukannya pendekatan-pendekan kritis untuk terus memajukan pemikiran islam dengan tidak hanya selesai di metode tradisional saja apalagi hanya dengan sudut pandang tertentu dalam melihat dan mengkaji teks-teks agama. ${ }^{20}$ Adanya dikotomi pengetahuan sering sekali dicontohkan dengan adanya perguruan tinggi pada masa awal sebagai salah satu institusi ilmu pengetahuan yang cenderung berdiri sendiri.

Ketiga, Tantangan Globalisasi, adanya dunia globalisasi yakni dengan berkembang pesatnya pengetahuan dan teknologi menjadi arus baru dalam memposisikan cara pandang tentang dunia sekitar termasuk dalam agama, bagaimana antara keduanya saling terhubungan antara satu wilayah dengan wilayah lain tanpa masih ditentukan oleh jarak dan waktu, bagaimana teknologi dapat berjejaring dengan sangat cepat tanpa masih melihat sekat-sekat antar satu dengan yang lainnya. Di tengah perkembangan zaman yang seperti ini yang secara kebetulan saling menghubungkan antara satu dengan yang lain menjadi satu persoalan baru, bagaiman umat muslim khususya dalam menghadapi hal demikian harus memiliki pemikiran dan pendidikan keislaman yang cukup memadai untuk dapat merespon berkembangnya kemajuan agar tidak tertinggal dan tidak hanya menjadi penonton dan korban dari ketatnya persaingan global. ${ }^{21}$

Keempat, Pendektan Studi Islam, dalam perkembanganya pemikiran islam selama ini menurutnya masih lebih banyak dominan menggunakan doktrinal-teologis dengan mengabaikan pendektan pendektan lain seperti pendekatan historis, empirikal dan pendekatan kritis sehingga dengan keterbatasan pendekatan tersebut menurut Amin Abdullah akan menyebabkan terjadinya klaim kebenaran. ${ }^{22}$

Bermula dari permasalahan tersebut, M. Amin Abdullah mencoba untuk memecahkannya dengan menawarkan gagasan Integrasi-Interkoneksi,

\footnotetext{
${ }^{20}$ Ahamad Izudin, Paradigama Integrasi-Interkoneksi, hlm. 114.

${ }^{21}$ M. Amin Abdullah, Studi Agama: Normattivitas Atau Historisitas? (Yogyakarta: Pustaka Pelajar, 2002), hlm. 93.

${ }^{22}$ M. Amin Abdullah, Falsafah Kalam di Era Postmodernisme (Yogyakarta: Pustaka Pelajar, 1995), hlm. 25.
} 
bagaimana berkesinambungannya antar satu disiplin ilmu dengan disiplin ilmu yang lain agar terciptanya kemaslahatan dengan meninggalkan klaim-klaim kebenaran yang hanya akan dapat memundurkan Islam. Proses panjang yang ia lakukan memakan waktu yang cukup lama bergelut dalam dunia akademis, bermula dari apa yang disebut dengan historisitas dan normativitas.

Amin Abdullah bertolak dengan pertentangan perdebatan antara teori empirisme dan rasionalisme barat, namun ontologis pengetahuan Amin Abdullah rupanya menurut alim ruswantoro banyak dipengaruhi oleh idealisme kritikal Emanuel Kunh. Bagaimana noumena atau yang disebut oleh amin dengan normativitas sebagai kebenaran absolut dan phenoumena yang disebut dengan historisitas sebagai kebenaran yang berasal dari pengalaman dan rasionalitas manusia, bagaimana pengalaman dan rasionalitas manusia dapat menemukan sesuatu dengan menyingkap kebenaran yang bersifat universal, meskipun tidak tertutup terhadap kebenaran yang bersifat absolut dikarenakan keterbatasan dalam menggapainya. Sehingga pengetahuan bagi kant adalah sesuatu yang tidak final karena berbeda di ruang dan waktu sehingga menuntut untuk adanya pembaruan. $^{23}$

Gagasan tentang normativitas dan historisitas Amin Abdullah dipengaruhi oleh Fadzlur Rahman dan M. Arkoun. Bagaimana wajah agama dipahami secara kaku dan tertutup, bagaimana kebenaran pemikiran islam dianggap sebagai kebenaran yang absolut yang sudah tidak bisa diperdebatkan. Menurut Arkoun, adanya klaim kebenaran pemikiran karena tidak dapat membedakannya antara bagaimana letak agama (Alquran dan Hadis) yang dipahami secara profan dan bagaimana agama diwilayah sakral yang tidak dapat diotak-atik rupanya masih dirasa sangat sulit, padahal menurutnya agama memiliki dua wajah yang tidak bisa disamakan sekaligus dibedabedakan.

${ }^{23}$ Alim Ruswatoro, Epistemologi Pemikiran Islam.., hlm. 36. 
Moch. Khoirul Walid, Integralistik-Interkonektif Pendidikan Salaf dan Khalaf Pondok Pesantren Tebuireng Jombang

DOI: https://doi.org/10.19105/rjpai.v2i2.4645

Dalam perkembangan pengatahuan antara profan dan sakral ini atau bahasanya Rahman antara normativitas dan historisitas ini masih kebanyakan seringkali terjebak diantara keduanya. Dalam pemikiran islam seharusnya bersifat historis karena tidak lepas dari konteks sosial, kultural, politik dan lain sebagainya, akan tetapi hasil dari pemikiran ini kemudian disakralkan oleh pemeluknya hingga kemudian kebenaran dari hasil pemikiran ini dijadikan sebagai kebenaran yang absolut, hal ini yang kemudian menyebabkan tertutupnya pemikiran atau tidak terbuka terhadap pemikiran lain yang berbeda dengan kelompok tertentu. Sehingga pada posisi ini kebenaran absolut dari pemikiran dirasa sejajar dengan kebenaran absolut dari agama (quran dan hadist). ${ }^{24}$

Pada posisi ini antara agama dan pikiran agama perlu digaris bawahi, agama dalam dunia akademik memiliki dua arti jika dilihat dari Arkun dan Khant, ketika agama dimaksudkan terhadap teks agama (alquran dan hadist) memiliki makna kebenaran yang absolut yang tidak bisa diganggu gugat, beda halnya ketika agama dimaksudkan terhadap hasil rumusan ulama, cendikiawan dan organisasi agama maka hal tersebut sudah berbeda arti karena ada satu dimensi memiliki kekurangan yang dapat dikritisi bahkan dapat dipertanyakan ulang sesuai dengan ruang dan waktu yang berbeda. ${ }^{25}$ Sehingga perlu adanya penegasan.

Persoalan terhadap kajian keagamaan yang baku ini yang kemudian selanjutnya membuka pemikiran lain bahwa hal tersebut tidak bisa diteruskan dalam sebuah pemikiran, dibutuhkan kajian historisitas sebagai pendekatan lain bahwa hal ini menurut Amin Abdullah tidak bisa ditinggalkan, adanya dua pendektan ini berfungsi untuk saling mengisi, mengoreksi dan memperbaiki kekurangan yang ada pada dua pendektan tersebut. Karena pada dasarnya pendekatan apapun dalam bidang studi termasuk agama tidak akan

\footnotetext{
24 Alim Ruswatoro, Epistemologi Pemikiran Islam, hlm. 13.

${ }^{25}$ Alim Ruswatoro, Epistemologi Pemikiran Islam, hlm. 20.
} 
menyelesaikan persoalan kemanusian secara sempurna kecuali saling mengisi datu dengan yang lainnya.

Selanjutnya sebagai salah satu gagasan yang kemudian banyak dibicarakan dari Amin Abdullah terkenal dengan integratif-interkonegtif yang mana sering diartikan dengan saling mengambil dan saling memberi antara satu tradisi dengan tradisi yang lain dalam hal ini bisa tradisi agama dan ilmu pengetahuan sekuler. Satu disiplin ilmu dapat memberi dan mengambil sesuatu yang kiranya dapat dipakai di bidang ilmu yang lain. Meskipun dalam hal ini, Amin Abdullah juga mengatakan bahwa tidak semua disiplin ilmu saling dapat integrasi, akan tetapi tidak bisa juga dikatakann berdiri terpisah tanpa terhubung, minimal dalam hal ini ada perjumpaan antara ilmu agama dan ilmu sekuler yang akan melahirkan kepekaan terhadap perlunya interkonesi. ${ }^{26}$

Adanya keterhubungan baik dari cara pandang dan pengambilan kesimpulan yang dapat dibandingkan terhadap yang lain akan melahirkan sikap terbuka dalam agama, sehinnga apa yang dihawatirkan dari awal terkait klaim kebenaran dapat diminalisir bahkan hingga ditiadakan karena sudah memiliki keterbukaan terhadap kelompok lain yang berbeda.

\section{KESIMPULAN}

Berawal dari gagasan M. Amin Abdullah tentang integrasi-interkoneksi yang mendasar dari keresahannya terhadap realitas yang terjadi, terkait bagaimana islam diwarnai dengan permusuhan antara satu dengan yang lainnya, bagaimana keegoisan pandangan sebagain kelompok terhadap kelompok lain yang kemudian saling memilliki sikap tertutup terhadap yang lain, bagaimana kelompok mayoritas dengan semena-menanya berbuat tidak adil terhadap minoritas dengan mengatas namakan agama. Berbagai macam persoalan yang terjadi tersebut, sebagai seorang yang telah cukup memiliki pengetahuan dan pengalam yang memadai seorang Amin Abdullah

${ }^{26}$ Alim Ruswatoro, Epistemologi Pemikiran Islam, hlm. 31-32. 
Moch. Khoirul Walid, Integralistik-Interkonektif Pendidikan Salaf dan Khalaf

Pondok Pesantren Tebuireng Jombang

DOI: https://doi.org/10.19105/rjpai.v2i2.4645

merumuskan pandangannya yang selama itu ia peroleh menjadi sebuah wacana hangat.

Berdasarkan pembahasan penulis bahwa integratif interkonektif pendidikan salaf dan kholaf pesantren Tebuireng Jombang berawal dari era globalisasi yang mengancam kehidupan masyarakat termasuk berdampak pada pendidikan serta berlakunya kurikulum nasional yang sudah terapkan di berbagai sekolah-sekolah dalam mengembangkan kompetensi siswa. Dengan demikian pesantren tebuireng mendirikan sekolah dan perguruan tinggi dengan mengikuti kurikulum yang diberlakukan dalam SKKB, serta tidak meninggalkan kajian salaf. Sehingga dalam setiap sekolah ada penambahan mata pelajaran yang berkaitan dengan kurikulum pesantren.

\section{DAFTAR PUSTAKA}

Abidin, Muhammad Zainal. Paradigma Islam; dalam Pengembangan Ilmu Integralistik: Membaca Pemikiran Kuntowijoyo. Banjarmasin: IAIN ANTASARI PRESS, 2016.

Abidin, Zainul. "Filsafat Ilmu-Ilmu Keislaman Integralistik: Studi Pemikiran Kuntowijoyo", Ilmu Ushuluddin, Vol. 13 No. 2. Juli 2014.

Azizah, Nur. "Hubungan Ilmu dan Agama dalam Perspektif Islam: Telaah Pemikiran Kuntowijoyo", Konferensi Integrasi Interkoneksi Islam dan Sains, Vol. 1. September 2018.

Fahmi, M. Islam Transendental; Menelusuri Jejak-jejak Pemikiran Islam Kuntowijoyo. Yogyakarta: Pilar Religia, 2005.

Https:/ / kbbi.web.id/objektif diakses pada 15 April 2020.

Mujahidin, Anwar. "Epistimologi Islam: Kedudukan Wahyu Sebagai Sumber Ilmu", Ulumuna: Jurnal Studi Keislaman, Vol. 17, No. 1. Juni 2013.

Muhadjir, Noeng. Filsafat Ilmu; Kualitatif dan Kuantitatif untuk Pengembangan Ilmu dan Penelitian, Ed. 3. Yogyakarta: Rake Saeasin, 2006.

Kuntowijoyo. Paradigma Islam Interpretasi untuk Aksi, Cet. 1. Bandung: Mizan 1991.

Islam sebagai Ilmu; Epistimologi, Metodologi, dan Etika, Ed. 1. Jakarta : Teraju 2005. 
Selamat Tinggal Mitos, Selamat Datang Realitas; Esai-esai Budaya dan Politik, Cet. 1. Bandung: Mizan, 2005.

Islam sebagai Ilmu; Epistimologi, Metodologi, dan Etika, Ed. 2. Yogyakarta: Tiara Wacana, 2006.

Kusmana. Paradigma al-Qur'an: Model Analisis Tafsir Maqasidi dalam Pemikiran Kuntowijoyo, AFKARUNA: Jurnal Ilmu-ilmu Keislaman, Vol. 11, No. 2. 2 Desember 2015.

Pettiford, Jill Steans dan Lioyd. Struktulaisme dalam Hubungan Internasional: Perspektif dan Tema. Yogyakarta: Pustaka Pelajar, 2009. 